\title{
Sawn timber recovery optimization in primary industry from legality aspect
}

\author{
Umar Atik $^{1 *}$, Mahawan Karuniasa ${ }^{2}$, and Yuki Wardhana ${ }^{1}$ \\ ${ }^{1}$ School of Environmental Science, Universitas Indonesia, Jakarta, 10430 Indonesia \\ ${ }^{2}$ Environment Institute, Jl. Lidar No. 5, Jatiasih, Bekasi, 17424 Indonesia
}

\begin{abstract}
To reduce deforestation and illegal logging several international initiatives have been carried out. Recognition of SVLK existence, among others, is through Forest Law Enforcement, Governance and TradeVoluntary Partnership Agreement (FLEGT-VPA) and Illegal Logging Prohibition Act (ILPA), which are proof of Indonesian Government's commitment to improving forest governance. Sistem Verifikasi Legalitas Kayu (SVLK) regulates compliance from forest management and timber trade aspect. Scope of SVLK audit covers from upstream to downstream forest governance, one of which is sawmill industry. Fulfilling the legality aspect of sawmill industry is mandatory in SVLK. SVLK also analyses wood traceability and sawmill activities in the industry. One of indicators used is sawn timber recovery of sawmills. The research was conducted using literature studies, descriptive analysis and comparative analysis of secondary data and regulations related to SVLK. Case study used as research object was Penggergajian Kayu (PK) Rimba Sari sawmill industry with production capacity of $<6,000 \mathrm{~m}^{3} /$ year in Banyumas. PK Rimba Sari generates of $59.34 \%$ sawn timber recovery. The study shows that there is potential for utilization of wood waste amounting to $40.66 \%$. So far, wood waste is only used for direct sales but no processing has been carried out yet. The objective of research is to analyze the optimization of sawn timber recovery concerning legality aspect of company as a form of compliance with SVLK scheme. This study concludes that researchers recommend an alternative use of wood waste as part of a sustainable industry and clean production.
\end{abstract}

\section{Introduction}

The rate of deforestation in Indonesia had become a systemic problem, so it needs to be addressed. Indonesia lost forest area of up to 33.4 million hectares in 2009 [1]. The leading cause of the increase in deforestation in Indonesia is illegal timber trade and illegal exploitation of forests. Therefore, the Government began to formulate a program as an initiative to overcome several problems regarding timber exploitation and illegal timber trade [2]. The Government has implemented Presidential Instruction No. 4/2005 and Regulation of Ministry of Forestry No. P.65/Menhut-II/2006 regarding eradicating illegal

\footnotetext{
* Corresponding author: umar.atik@gmail.com
} 
logging practice in forest areas and the wood distribution throughout Indonesia territory. Several agreements at international level related to eradicating illegal logging were signed with China in December 2002, with the United Kingdom in April 2002, in June 2003 with Japan, and in November 2006 with the United States [3].

The European Union (EU) reaffirmed its concern to tackle illegal logging in 2003, by establishing several regulations regarding the import of forest products and establishing Forest Law and Enforcement Governance and Trade (FLEGT) and opening Voluntary Partnership Agreements (VPA) with countries wishing to trade forest products with the EU [4]. FLEGT license is a requirement from EU to trade timber from tropical timberproducing countries through a Voluntary Partnership Agreement (VPA). Under this partnership agreement, partner countries urge to develop systems that can control timber legality verification to be exported to EU. The EU will help by providing several supports for establishing or perfecting such systems.

The essence of the partnership agreement is an agreement on the legal framework for verification of timber legality (Timber Legality Assurance System) from a partner country. For example, Indonesia has Sistem Verifikasi Legalitas Kayu (SVLK) as the Timber Legality Verification System, stipulating regulatory tools for the forestry sector, understanding legality definitions and developing a control system that ensures products timber that Indonesia exports to the EU complies with the regulations. This system is mandatory for all license holders for primary wood forest products processing to advanced wood processing industries and timber exporters. They are required to comply with this SVLK and obtain a V-Legal Document for export, specifically for export to the EU they must obtain a FLEGT license. Apart from the EU, The Indonesian Government has also agreed on cooperation with the Australian Government through the Country Specific Guideline. This collaboration acknowledges that SVLK is in line with the Illegal Logging Prohibition Act (ILPA) [5].

SVLK has a role in industry conformity assessment against audit standards. One of the verifiers contained in the audit standard is sawn timber recovery. The value of sawn timber recovery can be used as a reference in determining the level of production efficiency in the industry. In comparison, research conducted in the sawn timber industry in Cigudeg, West Java, stated that sawn timber recovery for processing logs into sawn timber was $56.52 \%$ [6]. Sawn timber recovery in the North America woodworking industry was up to $52.2 \%$, while other studies in the Nigerian industry sawn timber recovery is up to $45-55 \%$ [7] [8]. Wood waste generated from sawmills can have added value and potential for sustainable use. Thus, a strategy is needed to optimize the presence of wood waste.

Several challenges must be faced in the process of forest certification or timber legality verification. Research on the challenges of implementing a timber legality verification system has been carried out before; however, not many have linked it to the sawn timber recovery of sawmills. So, this is considered quite important to determine the condition of wood utilization. This research can provide an overview of the development of wood production in the sawmill industry, hoping that stakeholders can get information about the conditions in the application of timber legality verification. This study recommends several efforts that can be made as a form of utilizing wood waste to lead to a sustainable sawmill industry.

\section{Method}

This article focuses on the relationship between sawmills and timber legality aspects. This article uses descriptive study methods and comparative analysis as research methodologies. A literature review was conducted to study and compare forest governance initiatives nationally and internationally. This scientific article explains the foundations of the 
conceptual framework of this research, namely the SVLK concept and international cooperation initiatives based on previous scientific article literature studies. Furthermore, the sawn timber recovery calculation is analyzed from the legality aspect approach. Meanwhile, secondary data such as reports on timber production and other related documents were obtained from the Central Bureau of Statistics, the Ministry of Environment and Forestry, and PK Rimba Sari. These associated documents (reports, journals, reviews, articles, and data) are identified, reviewed, and analyzed. The research stage of the study are shown in Figure 1.

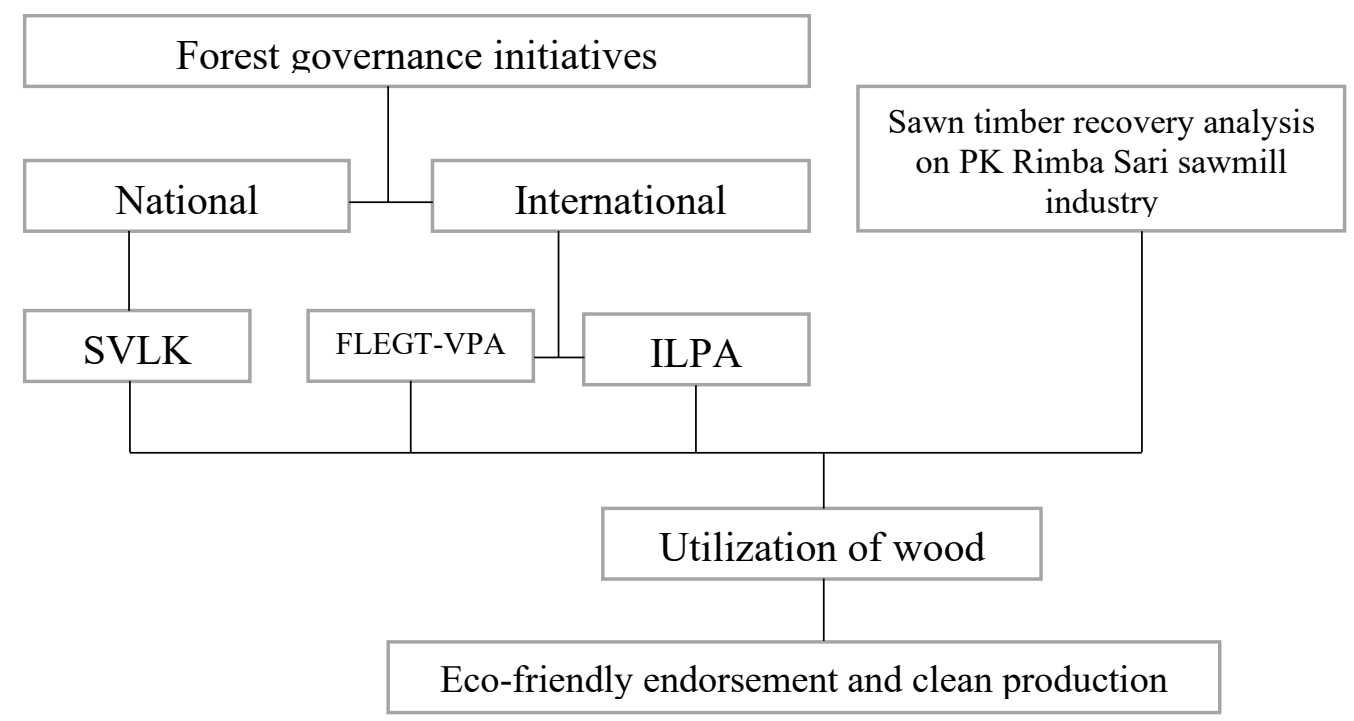

Fig. 1. Research Stage. Source: (Author, 2020)

\section{Results and discussion}

\subsection{Forest governance initiatives}

The Indonesian Government has taken initiatives that have far-reaching implications for reducing illegal trade and illegal logging practices. In terms of forest sustainability certification, Indonesia has a mandatory national system, namely Pengelolaan Hutan Produksi Lestari (PHPL) as the Sustainable Production Forest Management system [9]. While timber legality assurance is implemented in a chain of custody system known as the Timber Legality Assurance System (SVLK) [10]. To ensure Indonesia timber sourced and legality aspect, SVLK system is developed. Timber sourced could be originating from several forest statuses namely private forest and state forest. This system ensures legality and sustainable management. Implementing a wood traceability system is a mandatory for all management units those utilizing forest products from upstream even to downstream. Through SVLK, Indonesian timber products that are traded for export that obtained from state forests and community forests, are certified as sustainably managed products and legally guaranteed. The SVLK system support the competitiveness to face international market include Australia and EU countries [11].

FLEGT licenses are a requirement set by the EU in the context of timber trade from tropical timber-producing countries through a mechanism of VPA [9]. The FLEGT-VPA will be a targeted instrument for countries to sign VPA with the EU to demonstrate the 
legality of origin of wood [12]. Indonesia and EU started VPA negotiations in January 2007 but dialogue intensified after completing the SVLK after July 2009. SVLK is finally regulated in the Ministry of Forestry regulation No. P.38/Menhut-II/2009, which includes the assessment of SVLK and PHPL. The regulation has been revised for several times, the latest regulation of SVLK is P.30/Menlhk/Setjen/PHPL.3/3/2016. The requirements for the SVLK is the basic foundation of the VPA between EU and Indonesia. The main components of SVLK system are the definition of timber legality, timber transportation routes, independent verification, and a monitoring system [1][12]. The SVLK policy must be applied to all business stakeholders who use wood raw materials and their derivatives in Indonesia, namely, among others, state-owned forests managed by the community, stateowned forests, holders of timber utilization permits, small and medium-scale timber industries, and community forests, in which the forest is privately owned by the local community [3].

This cooperation agreed on the stipulation that the European market only approves legal timber. Requirements for implementing FLEGT-VPA are own a timber legality verification system and a common understanding regarding the definition of legal timber [12]. The Regulation of SVLK in Indonesia aims to preventing and eradicating the illegal logging issue. This regulation is in line with the European Union Timber Regulation number 995/2010, which was followed up by the FLEGT-VPA Agreement between EU and Indonesia. The agreement has been ratified through Presidential Regulation No. 21 of 2014, dated March 13th, 2014. Indonesia became the first Asian country to ratify a VPA [10]. Incentive received from the issuance of FLEGT documents means that wood products entering the EU will not be subject to due diligence.

The EU timber regulation consists of three main requirements, namely (1) prohibiting the entry of timber and timber derivative product from illegally logging into EU market, (2) Officers are those who supply wood products on the EU market - must carry out due diligence mechanism on the product and be able to show that they have carried out the due diligence, (3) Traders, who sell or buy timber products that have entered EU market, must maintain accurate information about customers and suppliers and to facilitate tracking of product supply chains across the EU [13].

Since FLEGT licensing is implemented, all Indonesian wood products based on the Ministry of Trade number 84/M-DAG/PER/12/2016 should be equipped by the V-legal document [14]. V-Legal documents are documents that state wood products for export already meet the standards timber legality verification following the provisions laws and regulations. Furthermore, FLEGT will be issued for export to EU and V-Legal documents for other countries markets. Indonesian National Accreditation Committee or Komite Akreditasi Nasional (KAN) accredits Conformity Assessment Bodies (CAB) as a third party Auditor who will audit forest and industrial management units. Based on http://silk.dephut.go.id, as of September 2020, there are 17 PHPL assessment bodies and 27 VLK assessment bodies, but only 26 institutions can issue V-Legal and FLEGT documents. The implementation of FLEGT encountered many challenges among industry players. No less needed extra support from the Minister of Environment and Forestry, Minister of Industry, Minister of Trade, and Minister of Foreign Affairs.

SVLK is made based on the agreement of forestry stakeholders that contains indicators, criteria, standards, verifiers, verification methods, and norms of assessment. All definitions from various stakeholders agreed on aspects of (1) mandatory policies, (2) verification standards, (3) traceability, (4) timber legality, (5) multi-stakeholder process, (6) verification method, and (7) system [3]. Stakeholders involved in SVLK include (1) Ministry of Environment and Forestry, (2) National Accreditation Committee, (3) Conformity Assessment Bodies (CAB), (4) Independent monitoring, (5) Forestry management unit. Each of these stakeholders has a complementary role in the SVLK process. Through the 
participation of stakeholders, it is hoped that SVLK can provide benefits and minimize challenges in SVLK implementation.

FLEGT licensing through the application of SVLK has a close relationship with the role of the Indonesian Government in supporting the enhancement of the competitiveness of the Indonesian timber industry. Through the application of the SVLK, producers are required to have a sustainable forest management certificate or a timber legality certificate to ensure that all timber harvested, processed, transported, and traded is legal. FLEGT licensing has increased the competitiveness and acceptability of Indonesian wood furniture in the EU market [11].

One of the wood products exported from Indonesia is furniture. Indonesia is the secondlargest furniture exporter after China, with destinations to the EU [11]. The export value of furniture, in general, has increased, as described in Figure 2 [15]. However, there was a decline in furniture exports to the EU during 2006-2015, while furniture exports from Vietnam to the EU experienced annual growth of 4.4\% [11]. The impact of the EU policy affects $96.4 \%$ of business units in China, where the majority of which $76.45 \%$ work in the SME sector [4].

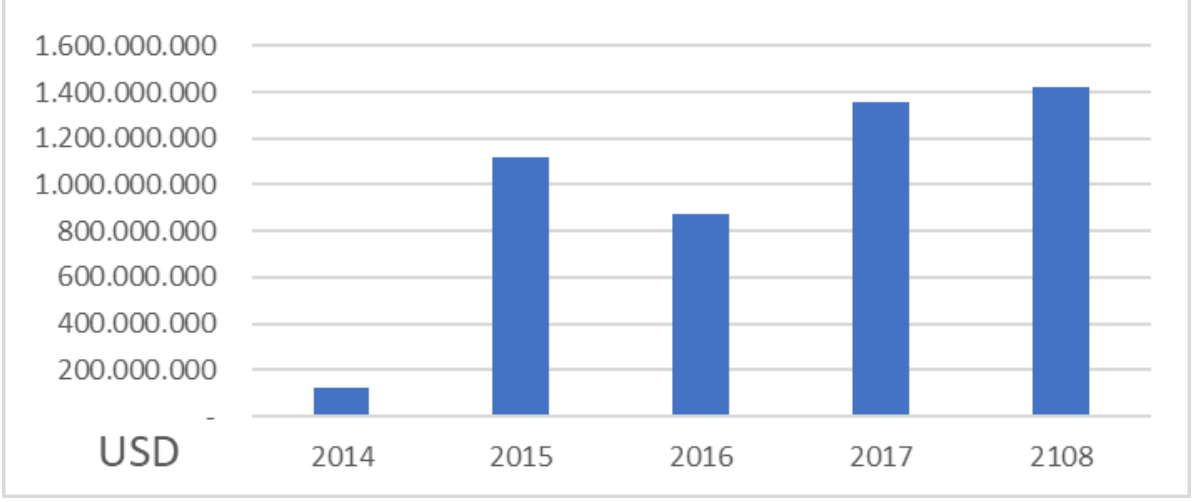

Fig. 2. Export Value of Indonesia Furniture. Source: (Ministry of Forestry, 2018)

The Australian Government and the Indonesian Government have agreed on the Country Specific Guideline [5]. This agreement regulates the terms related to timber that can be traded between the two countries. The same vision and mission regarding the eradication of both illegal trade and logging lead to Australia and Indonesia Cooperation. The Australian Government has implemented the Illegal Logging Prohibition Act (ILPA) scheme since 2012 to prevent illegal timber from entering the country [16]. In 2013, it was determined that starting November $30^{\text {th }} 2014$, ILPA will impose mandatory due diligence on imported timber. In 2014 Australia also gave recognition that the SVLK can comply with Australian regulations regarding ILPA (Illegal Logging Prohibition Act).

The obligation of a timber supply chain certification scheme as part of improved forest governance can reduce illegal logging activities as presented by the Ministry of Environment and Forestry; there has been a declining rate in illegal logging cases from 1,705 cases in 2006 to 29 cases in 2014 [11]. In some cases, common perceptions regarding the legality and governance of forestry also enforcement of regulatory mechanisms are necessary.

The trend of deforestation in Indonesia has decreased in the period 1990-2017, which can be seen in Figure 3. The highest deforestation occurred in 1996-2000, which was 3.51 
million hectares/year caused by severe forest fires [17]. In the next period, from 2002-2014, there was a decrease in the rate of deforestation, in line with forestry governance, a reduction in forest and land fires, and tight control over some access to decentralized forest management [17]. Government and stakeholder support can improve forestry governance to achieve the realization of sustainable forest management.

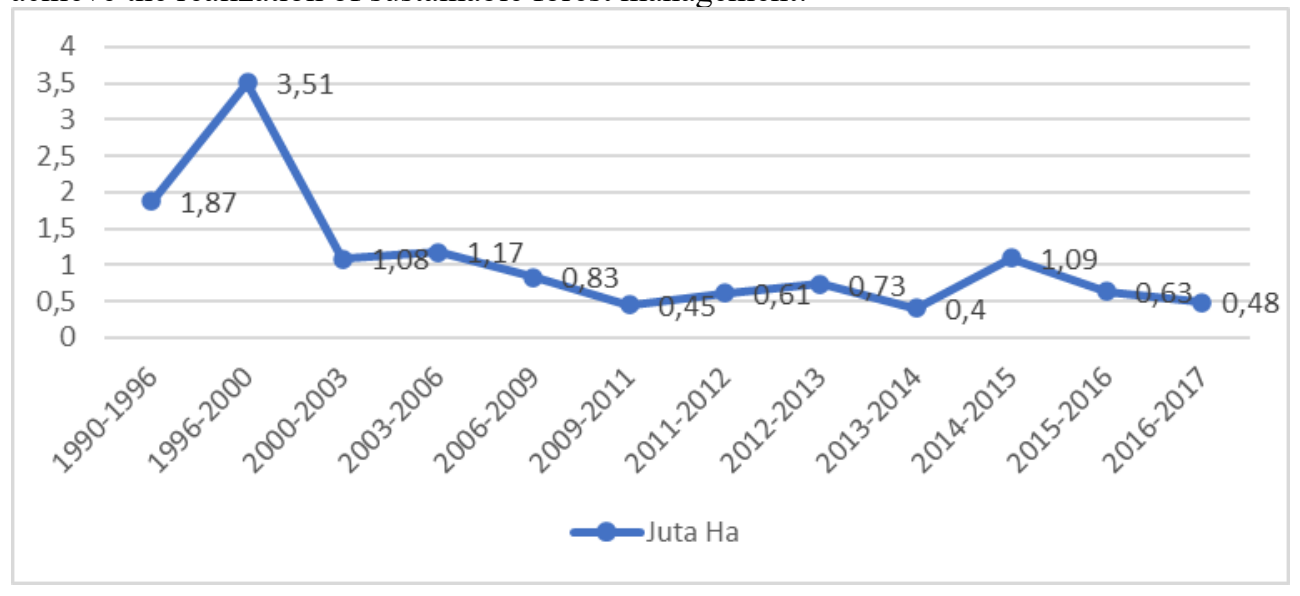

Fig. 3. Deforestation rate in Indonesia. Source: (Ministry of Forestry, 2018)

The use of wood in the industry must be carried out sustainably and responsibly. It is in line with Goal 9 of the Sustainable Development Goals, which is to build a strong infrastructure, promote an inclusive and sustainable industry and encourage innovation. The use of resources in the woodworking industry, for example, in the sawmill industry, must consider the responsibilities from an economic, ecological, and social perspective. Companies must remain financially stable so that the wheels of the economy keep running. The presence of sawmills is expected to increase labor absorption and create a multiplier effect from wood other than as the primary production. The utilization of wood waste from the by-product of sawn wood production is an added value for the industry as a form of efficient and environmentally friendly use of wood resources.

The woodworking industry is the third-largest industry in Indonesia, which has the enormous output in 2018 after the food industry and metal goods industry [18]. Increasing the competitiveness of forest products and exports can be done through certification provisions so that there are national standards that are referred to, reducing bureaucracy, and developing information systems. To increase Indonesian exports to have competitiveness in facing global competition and regional competition, the licensing process for production forest businesses must be simpler and more integrated.

It is undeniable that the implementation of SVLK still faces challenges. Some of the challenges that must be faced in the process of forest certification or verification of timber legality include (1) varying costs of certification while wood production is not the main income for the community, (2) community forests still apply traditional logging, which is always lower than the amount of cutting allowed, (3) there is no opportunity yet to set up a profitable timber industry to pay for certification costs, (4) communities have limited skills, information, and knowledge to provide forest inventory information and documentation to meet certification requirements [3][19]. The costs of the SVLK certification and surveillance audits are deemed burdensome for the management unit [10]. Complex certification standards based on professional management in developed countries often do not consider cultural values at the local level [20]. The implementation of SVLK is seen as an administrative redundancy in forest management, which impacts weak legitimacy, 
reduced cost efficiency, and low system effectiveness, especially in community forests [9]. Verification cost and the absence of premium price for SVLK verified timber hinders the management unit from implementing the SVLK [21].

In addition to the challenges faced, SVLK has several advantages, among others (1) a change in the forest management system from unwritten to written, (2) an increase in more formal and scientific forest management, (3) an ongoing monitoring and reporting function, (4) increasing professional status of several informal management units, (5) increasing knowledge, skills, and experiences related to the implementation of SVLK, (6) selfendorsement [2][3]. Increasing the professional status of the management unit can improve reputation and network additions. This also resulted in the introduction of certified management units. SVLK cannot promise an increase in product prices; however, those privileges can increase market opportunities and bring peace to the management unit because they have followed government regulations.

Thus, a formula is needed to be able to minimize challenges in SVLK implementation. It is hoped that the VLK audit fee adjustment will be more affordable by the management unit. Stakeholders can coordinate regarding these cost issues, considering that there are already many schemes that offer convenience in providing SVLK audit assistance from the Government. It is hoped that access to audit financing assistance can be socialized to management units, especially those with small management units. Socialization of the SVLK should continue to be carried out to promote the obligations of the SVLK. This socialization was also followed by mentoring so that it was able to facilitate the management unit in preparing for the SVLK audit.

\subsection{Sawn timber recovery analysis}

Sawn timber recovery is the comparison value between sawn timber output and log input in the sawmill industry expressed in units of a percent [6]. PK Rimba Sari is a sawmill industry that processes logs from community forests and Perum Perhutani. The company has a license of Timber Forest Product Processing Industry or Izin Usaha Industri Pengolahan Hasil Hutan Kayu (IUIPHHK) with a permit capacity of $<6,000 \mathrm{~m}^{3} /$ year. Based on the production report for three years, namely 2017-2019, it is known that the sawn timber recovery of wood processing reached $59.34 \%$. The sawn timber recovery is obtained from processing logs into sawn wood. Table 1 shows the wood processing data for the 2017-2019 period in PK Rimba Sari.

Table 1. PK Rimba Sari production report. (Source: PK Rimba Sari, 2020)

\begin{tabular}{|c|c|c|c|c|}
\hline Year & Log $\left(\mathbf{m}^{\mathbf{3}}\right)$ & Sawn timber $\left(\mathbf{m}^{\mathbf{3}}\right)$ & $\begin{array}{c}\text { Sawn timber } \\
\text { recovery }\end{array}$ & Year \\
\hline 2017 & $4,818.73$ & $3,163.52$ & $65.65 \%$ & 2017 \\
\hline 2018 & $5,555.20$ & $3,207.55$ & $57.74 \%$ & 2018 \\
\hline 2019 & $4,706.37$ & $2,570.60$ & $54.62 \%$ & 2019 \\
\hline Total & $\mathbf{1 5 , 0 8 0 . 3 0}$ & $\mathbf{8 , 9 4 1 . 6 8}$ & $\mathbf{5 9 . 3 4 \%}$ & Total \\
\hline
\end{tabular}

Wood waste generated from processing is $40.66 \%$, equivalent to $6,138.62 \mathrm{~m}^{3}$. The volume of wood waste generated for three years is equal to 90 containers with 40 feet size. The wood waste produced has not been utilized as a by-product and is only sold to factories that need fuel for boilers and stoves. Various potentials from the utilization of wood waste 
can be carried out to achieve clean production in the company and increase the added value of wood. Of course, this requires funding, infrastructure, facilities, and human resources. However, initiating the use of wood waste can be an effort to reduce the exploitation of forest resources.

\subsection{Utilization of wood waste}

Support from the Government regarding the use of wood waste in the industry can be a pioneer to improve sustainability in terms of the continuity of wood production. Wood processing industries that utilize wood waste as raw material for derivative products can be given appreciation and incentives. Thus, companies will be more eager to participate in utilizing wood waste. Wood waste has the potential to be used for various purposes. Derivate timber products such as particle boards, craft materials, furniture, and so on can use material from wood waste. Besides, the residue from the utilization of forest resources can be used as raw material for bioenergy [22]. The utilization of wood waste can provide a circular economy effect. Economic circulation creates opportunities to take advantage of the production chain [23].

\subsection{Eco-friendly endorsement and clean production}

Concerning the legality aspect, the Government as the regulator can include provisions on the utilization of industrial wood waste production in regulations related to SVLK. This provision is expected to be the basis for a clean and environmentally friendly industrial process following the SDGs Goal. The provisions contained in the SVLK regulations have so far not accommodated the requirements for industry to be able to utilize further the wood waste produced. Based on P.14/PHPL/SET/4/2016 regarding the SVLK assessment standard, it is stated in verifier 2.1.1.e that industries can accept wood waste raw materials to be used as raw material for production. However, there are no provisions regarding the continued use of wood waste produced to become a value-added derivative product. The Government has been able to introduce SVLK as an instrument for improving forestry governance. The SVLK policy supports improved forest governance with a percentage of improved law enforcement by $46 \%, 45 \%$ accountability, $43 \%$ participation, $42 \%$ transparency, and $31 \%$ coordination [24].

Also, the Government can provide endorsements as part of the SVLK for products that use wood waste as the primary raw material. The message conveyed from this endorsement is related to clean production that has been carried out by the company so that the company is recognized as being able to minimize the environmental impact of wood waste. The framework for implementing environmentally friendly products considers mitigation approaches and environmental impacts [25]. Socialization related to environmentally friendly products originating from a clean industrial production process is essential. The market for green products usually faces limitations in effective communication and products issued [26]. So it is necessary to formulate regulations that are synergized with market needs. Thus, it is hoped that market players will find out the origin of the products purchased that are sourced from environmentally friendly activities.

\section{Conclusion}

1. The implementation of the SVLK still requires support from the parties so that it can minimize the challenges that are currently occurring. The role of stakeholders is vital in strengthening the SVLK as a governance system owned by Indonesia. SVLK is the 
basis of an international cooperation agreement that supports eradicating illegal logging-illegal trading and creates ideal forest governance.

2. SVLK is a mandatory requirement for management units regulated in P.30/Menlhk/Setjen/PHPL.3/3/2016. The legality aspect is one of the things referred to in the SVLK assessment. Optimizing the sawn timber recovery of sawmills can be done through the utilization of wood waste that has been produced. Derivate timber can use raw material from wood waste.

3. The optimization of sawn timber recovery through the utilization of wood waste can be seen from the legality aspect. Efforts that can be taken include recommendations for clean industrial process provisions regarding the continued use of the wood waste produced to become a value-added derivative product in the SVLK regulations and the initiation of endorsements for products made from industrial wood waste.

4. Further studies are needed to see the market acceptability of products made from wood waste and their relationship to social sustainability in the communities around the factory.

\section{Acknowledgements}

We thank PK Rimba Sari for providing data, and the first author thanks his family and supervisors for their support. We also thank two reviewers and the editor of this article whose comments and suggestions improved the quality and relevance of the paper.

\section{References}

1. Prasetyo, A., Hewitt, J. \& Keong, C. H. Indonesia: Scoping Base Line Information for Forest Law Enforcement, Governance and Trade. (2012).

2. Brown, D. et al. Legal Timber Verification and Governance in the Forest Sector. Overseas Development Institute (ODI) (Overseas Development Institute (ODI), 2008).

3. Susilowati, D. Evaluation of Sistem Verifikasi Legalitas Kayu (Svlk) And Local Practice in Community Forest. 1-19 (2014).

4. Zeng, Y., Zeng, W., Qin, G. N., Zhu, Y. \& Huang, B. An Impact Assessment of the EU Timber Regulation on Small and Medium Sized Enterprises in China's Wood Product Industry. (2012).

5. Leipold, S., Sotirov, M., Frei, T. \& Winkel, G. Protecting 'First world' markets and 'Third world' nature: The politics of illegal logging in Australia, the European Union and the United States. Glob. Environ. Chang. 39, 294-304 (2016).

6. Laksono, A. D., Susdiyanti, T. \& M, K. B. Sawmill Industry Productivity and Rendemen in Cigudeg District, Bogor Regency. Nusa Sylva 16, 50-58 (2016).

7. Ogunwusi, A. A. Wood Waste Generation in the Forest Industry in Nigeria and Prospects for Its Industrial Utilization. Civ. Environ. Res. 6, 62-69 (2014).

8. Bowyer, J., Bratkovich, S. \& Fernholz, K. Utilization of Harvested Wood By the North American. (2012).

9. Nurrochmat, D. R., Dharmawan, A. H., Obidzinski, K., Dermawan, A. \& Erbaugh, J. T. Contesting National And International Forest Regimes: Case Of Timber Legality Certification For Community Forests In Central Java, Indonesia. For. Policy Econ. 68, 54-64 (2016).

10. Neupane, P. R. et al. How REDD+ and FLEGT-VPA Processes are Contributing Towards SFM in Indonesia-The Specialists' Viewpoint. Int. For. Rev. 21, 460-485 (2019). 
11. Lubis, M., Suharjo, B., Nurmalina, R. \& Purnomo, H. Effect of Forest Law Enforcement Governance and Trade License on competitiveness of Indonesian wooden furniture in the European Union market. Int. J. Manag. Econ. Invent. 04, 1936-1942 (2018).

12. Simula, M., Ghazali, B. H., Atyi, R. E. \& Contreras, O. P. Developments and Progress in Timber Procurement Policies as Tools to Promote Sustainable Management of Tropical Forests. Report prepared for the Internatioanl Tropical Timber Organization (2009).

13. Saunders, J. \& Reeve, R. The EU Timber Regulation and CITES. (2014).

14. Puruwita, I. \& Oktora, S. I. Exports and Competitiveness of Indonesian Plywood. Adv. Econ. Bus. Manag. Res. 98, 108-112 (2019).

15. Kementrian Lingkungan Hidup dan Kehutanan. Statistik Direktorat Jenderal PHPL Tahun 2018. (2018).

16. Daniela Kleinschmit, Stephanie Mansourian, Christoph Wildburger, A. P. Illegal Logging and Related Timber Trade - Dimensions, Drivers, Impacts and Responses: A Global Scientific Rapid Response Assessment Report. IUFRO World Ser. 35, $1-$ 146 (2016).

17. Kementerian Lingkungan Hidup dan Kehutanan. Status Hutan dan Kehutanan Indonesia 2018. Kementerian Lingkungan Hidup dan Kehutanan RI (2018).

18. Badan Pusat Statistik. Statistik Indonesia 2019. Statistik Indonesia 2019 (Indonesian statistics) (2019).

19. Maryudi, A. et al. Smallholder Farmers' Knowledge of Regulations Governing the Sale of Timber and Supply Chains in Gunungkidul District, Indonesia. Small-scale For. 16, 119-131 (2017).

20. Molnar, A. et al. Forest certification and communities. Int. For. Rev. 6, 173-180 (2004).

21. Susilawati, D., Kanowski, P., Setyowati, A. B., Resosudarmo, I. A. P. \& Race, D. Compliance of smallholder timber value chains in East Java with Indonesia's timber legality verification system. For. Policy Econ. 102, 41-50 (2019).

22. González-García, S. \& Bacenetti, J. Exploring the production of bio-energy from wood biomass. Italian case study. Sci. Total Environ. 647, 158-168 (2019).

23. Oliveira, F. R. de, França, S. L. B. \& Rangel, L. A. D. Challenges and opportunities in a circular economy for a local productive arrangement of furniture in Brazil.

Resour. Conserv. Recycl. 135, 202-209 (2018).

24. Miniarti, Y., Wardhana, Y. M. A. \& Abdini, C. The Success of SVLK in Supporting the Improvement of Forest Governance. J. Anal. Kebijak. Kehutan. 15, 55-66 (2018).

25. Razif, M. \& Persada, S. F. Environmental impact assessment (EIA) framework for ekolabel certification initiative in indonesia: Case study of a rattan-plywood based furniture industry. Int. J. ChemTech Res. 9, 634-643 (2016).

26. Cai, Z., Xie, Y. \& Aguilar, F. X. Eco-label credibility and retailer effects on green product purchasing intentions. For. Policy Econ. 80, 200-208 (2017). 